\title{
EFFECTIVENESS OF TREFFINGER MODEL APPLICATION TO IMPROVE STUDENT LEARNING OUTCOMES OF SENIOR HIGH SCHOOL ON OPTICAL MATERIALS
}

\author{
Wan Rifka Wulandari*1), Azizahwati $^{2)}$, Zuhdi Ma'aruf ${ }^{3}$ \\ ${ }^{1,2,3)}$ Physics Education, Riau University \\ e-mail: ${ }^{*}$ wanrifkawulandari@gmail.com \\ azizahwati@lecturer.unri.ac.id \\ zuhdim@yahoo.co.id
}

\begin{abstract}
The physics learning process at school does not involve students directly which causes the low cognitive learning outcomes of students. For this reason, it is necessary to apply an effective learning model for improving student learning outcomes. One suitable learning model is the treffinger learning model. The treffinger model provides learning activities with three stages namely basic tools, practice with the process, and working with real problems. These three stages can make students actively and creatively involved in the learning process. The purpose of this research is to find out the effectiveness of increasing cognitive learning outcomes of students on optical material by applying the treffinger learning model. This type of research is a quasi-experimental design with a non-equivalent control group design. The research sample was taken two classes randomly as the experimental class and the control class from the student population in class XI IPA of SMA Negeri 9 Pekanbaru. The data collection instrument used students' cognitive learning achievement test consisting of pretest and posttest given to the experimental class and the control class. Data were analyzed using descriptive and inferential analysis. Descriptive analysis results obtained an average absorption capacity of $72.64 \%$ experimental class with a good learning category and $63.47 \%$ control class with quite a good category. With the results of the inferential analysis with an independent-sample t-test, there are significant differences in learning outcomes between the experimental class and the control class, where the experimental class has a higher increase in learning outcomes. Thus the use of the treffinger model is effective in improving student learning outcomes in class XI IPA of SMA Negeri 9 Pekanbaru on optical material.
\end{abstract}

Keywords: treffinger model, cognitive learning outcomes, optics. 


\title{
EFEKTIVITAS PENERAPAN MODEL TREFFINGER UNTUK MENINGKATKAN HASIL BELAJAR SISWA SMA PADA MATERI OPTIK
}

\author{
Wan Rifka Wulandari ${ }^{* 1}$, Azizahwati $^{2)}$, Zuhdi Ma'aruf ${ }^{3}$ \\ $\left.{ }^{*} 1,2,3\right)$ Pendidikan Fisika, Universitas Riau
}

\begin{abstract}
Abstrak
Proses pembelajaran fisika di sekolah cenderung kurang melibatkan siswa secara langsung yang menyebabkan rendahnya hasil belajar kognitif siswa. Untuk itu, perlu diterapkan suatu model pembelajaran yang efektif dalam meningkatkan hasil belajar siswa. Salah satu model pembelajaran yang sesuai yaitu model pembelajaran treffinger. Model treffinger memberikan kegiatan belajar dengan tiga tahapan yaitu basic tools, practice with process, dan working with real problem. Ketiga tahapan tersebut dapat membuat siswa terlibat secara aktif dan kreatif dalam proses pembelajaran. Tujuan penelitinan ini untuk mengetahui efektivitas peningkatan hasil belajar kognitif siswa pada materi optik dengan penerapan model pembelajaran treffinger. Jenis penelitian yang digunakan adalah kuasi eksperimen dengan rancangan non-equivalent control group design. Sampel penelitian diambil dua kelas secara random sebagai kelas eksperimen dan kelas kontrol dari populasi siswa di kelas XI IPA SMA Negeri 9 Pekanbaru. Instrumen pengumpulan data menggunakan tes hasil belajar kognitif siswa yang terdiri dari pretest dan posttest yang diberikan pada kelas eksperimen dan kelas kontrol. Data dianalisis menggunakan analisis deskriptif dan inferensial. Hasil analisis deskriptif diperoleh daya serap rata-rata kelas eksperimen 72,64\% dengan kategori pembelajaran baik dan kelas kontrol 63,47\% dengan kategori cukup baik. Hasil analisis inferensial dengan independent-sample ttest, terdapat perbedaan hasil belajar yang signifikan antara kelas eksperimen dan kelas kontrol, dimana kelas eksperimen lebih tinggi peningkatan hasil belajarnya. Dengan demikian penggunaan model treffinger efektif dalam meningkatkan hasil belajar siswa kelas XI IPA SMA Negeri 9 Pekanbaru pada materi optik.
\end{abstract}

Kata kunci: model treffinger, hasil belajar kognitif, optik.

\section{Pendahuluan}

Sistem pendidikan Indonesia terus mengalami perubahan. perubahan tersebut dilakukan dalam rangka peningkatan mutu pendidikan, sehingga diperlukan perubahan paradigma dalam menelaah proses belajar siswa dan interaksi antara siswa dan guru (Nurpatmawati et al., 2017).

Menurut Suharsimi Arikunto, (2016), pada dasarnya dunia pendidikan saat ini menjurus kepada siswa yang dituntut agar lebih aktif, kreatif, dan inovatif dalam memahami materi pelajaran, karena masalah utama pembelajaran saat ini adalah masih rendahnya tingkat pemahaman siswa yang dapat dilihat dari rata-rata hasil belajar. Kebanyakan sekolah memfokuskan perhatiannya pada kecerdasan siswa. Para siswa tersebut dituntut untuk selalu belajar dan memenuhi standar kurikulum pendidikan yang tak jarang sangat memberatkan siswa. Sangat sulit ditemukan sekolah yang memberikan perhatian pada kreativitas siswa, sehingga yang ditekankan pada siswa adalah keterampilan-keterampilan rutin dan hafalan semata (Andriyani Anik, 2015). Permasalahan ini sering terjadi pada mata pelajaran sains yang meliputi biologi, kimia, dan fisika.

Fisika merupakan suatu cabang ilmu pengetahuan alam yang memegang peranan penting dalam perkembangan sains dan teknologi, sehingga pembentukan pola pikir yang baik pada siswa perlu dilakukan. Pembelajaran fisika berkaitan dengan cara mencari tahu tentang alam secara matematis, sehingga untuk memahami fisika bukan hanya mengumpulkan fakta-fakta, konsep atau prinsip saja, tetapi juga proses penemuan (Rizki Amalia, 2012). Proses penemuan oleh siswa dapat diaplikasikan dalam proses pembelajaran jika siswa terlibat secara aktif 
dan kreatif. Akan tetapi pembelajaran fisika di sekolah cenderung sangat teoritik dan pasif seperti di SMA Negeri 9 Pekanbaru.

Berdasarkan informasi yang diperoleh dari guru mata pelajaran fisika SMA Negeri 9 Pekanbaru, menyatakan bahwa nilai rata-rata ujian peserta didik khususnya pada materi optik masih rendah yaitu 61,5 yang menandakan nilai rata-rata masih di bawah 70 , yang artinya belum mencapai kriteria ketuntasan minimum (KKM). Materi optik merupakan materi yang cukup sulit untuk dipahami sebagian siswa di SMA Negeri 9 Pekanbaru. Guru juga melihat kurangnya minat siswa dalam mata pelajaran fisika dan kegiatan pembelajaran masih cenderung menggunakan metode konvensional yaitu ceramah dan masih berpusat pada guru.

Untuk mengatasi masalah tersebut, guru harus melakukan perubahan, salah satu inovasi yang dapat dilakukan oleh guru adalah pemilihan model pembelajaran yang sesuai. Salah satu model pembelajaran yang dapat diterapkan adalah model pembelajran treffinger. Model pembelajaran treffinger adalah model pembelajaran yang melibatkan proses pembelajaran siswa lebih aktif dan kreatif dalam membangun pemahaman dari pengalaman yang telah dimiliki dengan pengalaman baru. Pada model pembelajaran treffinger, proses penemuan informasi atau penemuan konsep menjadi kunci utama, sehingga konsep yang diperoleh siswa tersimpan lebih lama dalam ingatan dibandingkan dengan cara bercerita (Muhammad Noer, 2014).

Model treffinger merupakan salah satu model yang menangani masalah kreativitas secara langsung. Temuan empiris Lusi Rahmawati (2015) dan Williyatimas (2005), menunjukkan bahwa siswa dengan taraf sekolah menengah mengalami peningkatan yang signifikan dalam hal kemampuan memecahkan masalah secara kritis yang diberikan perlakuan dengan menerapkan model pembelajaran treffinger. Berdasarkan permasalahan tersebut, maka dilakukan penelitian mengenai penerapan model pembelajaran treffinger untuk meningkatkan hasil belajar kognitif siswa pada materi optik di SMA Negeri 9 Pekanbaru.

\section{Bahan dan Metode}

Penelitian dilakukan di SMA Negeri 9 Pekanbaru pada kelas XI yang sampelnya terdiri dari 36 orang kelas eksperimen dan 36 orang kelas kontrol. Jumlah populasi penelitian adalah 252 orang siswa kelas XI IPA. Waktu penelitian dilakukan pada semester genap tahun ajaran 2018/2019.

Jenis penelitian menggunakan penelitian quasi experimental design, dengan ancangan non-equivalent control group design (Sugiyono, 2017). Pada rancangan ini sampel diambil dari populasi kemudian dikelompok kan menjadi dua yaitu kelompok eksperimen dan kelompok kontrol. Kelas eksperimen menerapkan model pembelajaran treffinger, sedangkan pada kelas kontrol diterapkan pembelajaran konvensional. Kemudian dilanjutkan dengan pemberian pretest dan posttest kepada kelas eksperimen dan kelas kontrol.

Tabel 1. Katagori daya serap siswa dan efektivitas pembelajaran

\begin{tabular}{cll}
\hline Interval & $\begin{array}{c}\text { Kategori } \\
\text { Daya Serap }\end{array}$ & $\begin{array}{c}\text { Kategori } \\
\text { Efektivitas }\end{array}$ \\
\hline $85 \leq \mathrm{x} \leq 100$ & Sangat baik & Sangat efektif \\
$70 \leq \mathrm{x}<85$ & Baik & Efektif \\
$50 \leq \mathrm{x}<70$ & Cukup baik & Cukup efektif \\
$0 \leq \mathrm{x}<50$ & Kurang baik & Kurang efektif \\
\hline
\end{tabular}

Sumber: (Depdiknas, 2007).

Instrumen yang digunakan untuk mengumpulkan data pada penelitian adalah tes hasil belajar kognitif siswa pada materi optik yang diberikan sebagai pretest dan posttest, yang terdiri dari 20 soal pilihan berganda dan telah di validasi. Hasil yang diperoleh dari tes hasil belajar kognitif dianalisis menggunakan teknik analisis deskriptif dan analisis inferensial. Pada teknik analisis deskriptif, data yang didapat kemudian dianalisis untuk melihat gambaran hasil belajar kognitif siswa dengan menggunakan kriteria daya serap dan efektivitas pembelajaran yang mengacu pada Tabel 1.

Analisis inferensial dilakukan dengan melakukan uji hipotesis untuk mengetahui 
perbedaan hasil belajar kognitif siswa setelah diterapkan model treffinger pada kelas eksperimen, sedangkan pada kelas kontrol diterapkan model konvensional. Pengujian hipotesis dilakukan apabila data yang diperoleh terdistribusi normal dan homogen.

\section{Hasil dan Pembahasan}

Berdasarkan penelitian ini, terdapat dua variabel yaitu variabel bebas dan variabel terikat, sebagai variabel bebas adalah model treffingger, sedangkan variabel terikat adalah hasil belajar kognitif siswa SMA yang dianalisis menggunakan analisis deskriptif dan analisis inferensial. Hasil posttest yang diperoleh dari kelas eksperimen dan kelas kontrol dapat dilihat pada Tabel 2.

Berdasarkan Tabel 2 daya serap rata-rata setelah dilakukan posttest untuk kelas eksperimen dan kontrol terdapat perbedaan dengan rentang nilai kedua kelas sebesar $5 \%$. Keempat kategori dari Tabel 2 menyatakan jumlah siswa yang mendapatkan kategori daya serap pada kategori amat baik, baik, cukup baik dan kurang baik. Persentase siswa dari kelas eksperimen sebanyak 29,73\% mendapat kan hasil belahjar kategori amat baik dengan jumlah siswa 11 orang dan $27,02 \%$ berkategori baik, sedangkan pada kelas kontrol tidak ada hasil belajar siswa pada kategori amat baik dengan jumlah siswa 20 orang dan 55,56\% berkategori baik. Dengan demikian hasil belajar pada kelas eksperimen lebih tinggi dibandingkan kelas kontrol.

Perbedaan tingginya nilai daya serap disebabkan oleh proses pembelajaran di kelas eksperimen menerapkan model pembelajaran treffinger, dimana dengan pembelajaran seperti ini, siswa dapat mengembangkan ide atau gagasan yang dimilikinya dengan mengguna kan LKPD yang telah disediakan oleh guru, sehingga dengan pembelajaran ini siswa akan lebih aktif dalam proses pembelajaran dan lebih lama mengingat konsep fisika. Hal ini didukung oleh penelitian yang dilakukan oleh Sari \& Putra (2015) yang menyatakan bahwa model pembelajaran treffinger adalah model pembelajaran yang melibatkan proses aktif siswa dalam membangun pemahaman dari pengalaman yang telah dimiliki dengan pengalaman baru. Pada model pembelajaran treffinger, proses penemuan informasi atau penemuan konsep menjadi kunci utama, sehingga konsep yang diperoleh siswa tersimpan lebih lama dalam ingatan dibandingkan dengan cara bercerita, sedangkan pada kelas kontrol yang menerapkan model pembelajaran konvensional, siswa hanya mendengarkan penjelasan dari guru, sehingga siswa kurang aktif dalam proses pembelajaran dan pengetahuan yang didapat kurang luas.

Hasil pretest dan postest yang diberikan menunjukkan efektivitas pembelajaran yang dapat ditunjukkan pada Tabel 3. Penerapan model treffinger pada materi optik, sangat memberikan dampak positif dengan terjadinya kenaikan hasil belajar kognitif pada kelas eksperimen, sehingga terbentuknya pembelajaran yang efektif yang mampu membantu siswa dalam memahami materi pelajaran. Akan tetapi, pembelajaran konvensional yang sesuai dengan pola guru mengajar di sekolah untuk materi optik memberikan dampak positif juga yang dapat meningkatkan hasil belajar, namun pembelajaran konvensional mengalami peningkatan dengan kategori cukup efektif apabila diterapkan pada materi optik.

Tabel 2. Daya serap rata-rata posttest siswa

\begin{tabular}{|c|c|c|c|c|c|c|}
\hline \multirow[b]{2}{*}{ No } & \multirow[b]{2}{*}{ Interval (\%) } & \multirow[b]{2}{*}{ Kategori } & \multicolumn{2}{|c|}{ Kelas Eksperimen } & \multicolumn{2}{|c|}{ Kelas Kontrol } \\
\hline & & & $\%$ & $\begin{array}{c}\text { Jumlah } \\
\text { siswa }\end{array}$ & $\%$ & $\begin{array}{c}\text { Jumlah } \\
\text { siswa }\end{array}$ \\
\hline 1 & $85-100$ & Amat baik & 29,73 & 11 & 0 & 0 \\
\hline 2 & $70-84$ & Baik & 27,02 & 10 & 55,56 & 20 \\
\hline 3 & $50-69$ & Cukup baik & 40,54 & 15 & 41,67 & 15 \\
\hline 4 & $0-49$ & Kurang baik & 0 & 0 & 2,77 & 1 \\
\hline \multicolumn{2}{|c|}{ Rata-rata } & & 72,64 & \multicolumn{3}{|c|}{67,64} \\
\hline \multicolumn{2}{|c|}{ Kategori } & & Baik & \multicolumn{3}{|c|}{ Cukup baik } \\
\hline
\end{tabular}


Tabel 3. Efektivitas pembelajaran posttest siswa

\begin{tabular}{clcc}
\hline No & Kelas & $\begin{array}{c}\text { Daya serap } \\
\text { rata-rata } \\
\text { kelas }\end{array}$ & Kategori \\
\hline 1 & Eksperimen & 72.64 & Efektif \\
2 & Kontrol & 67,64 & $\begin{array}{c}\text { Cukup } \\
\text { Efektif }\end{array}$ \\
\hline
\end{tabular}

Hasil efektivitas pembelajaran yang diperoleh kelas eksperimen adalah 72,64, sedangkan kelas kontrol adalah 67,64. Oleh sebab itu, efektivitas pembelajaran yang diperoleh kedua kelas adalah efektif dan cukup baik. Artinya penggunaan model treffinger татри memberikan peningkatan hasil belajar lebih baik. Hal ini juga dapat dilihat dari hasil independent samples test yaitu nilai $\mathrm{t}=2,675$, signifikansi $p=0,009(p<0.05)$ yang artinya terdapat perbedaan yang signifikan hasil belajar kognitif siswa melalui penerapan model treffingger dan pembelajaran konvensional. Selain itu, data hasil belajar diuji menggunkan independent sample t-test, untuk mengetahui apakah tidak terdapat perbedaan yang signifikan antar kelas eksperimen dan kelas kontrol. Setelah itu dilakukan pengujian paired sample t-test menunjukkan peningkatan hasil belajar siswa sebelum dan sesudah pembelajaran menggunakan model treffingger dan pembelajaran konvensional, untuk melihat apakah ada peningkatan yang signifikan. Hasil dari pengujian tersebut dapat dilihat pada Tabel 4.

Uji $t$ yang dilakukan adalah untuk menguji hipotesis $\mathrm{H}_{\mathrm{o}}$ dimana pada hasil pretest, output independent-sample t-test kedua kelas diperoleh $\mathrm{t}=70$, signifikansi $p=$ $0,602(p>0,05)$, hasil ini menunjukkan bahwa
$\mathrm{H}_{\mathrm{o}}$ diterima. Oleh karena itu, dari data pretest yang didapatkan adalah tidak terdapat perbedaan yang signifikan sebelum diberikan treatment pembelajaran terhadap peningkatan hasil belajar kognitif siswa.

Output dari paired sample t-test juga menunjukkan peningkatan hasil belajar siswa sebelum dan sesudah pembelajaran menggunakan model treffingger dan pembelajaran konvensional, nilai signifikansi yang didapatkan adalah $\mathrm{t}=-17,637, p=0,000$ $(p<0,05)$, dan untuk kelas eksperimen dan $\mathrm{t}=$ $-17,621, p=0,000(p<0,05)$ untuk kelas kontrol, sehingga $\mathrm{H}_{\mathrm{o}}$ ditolak yang artinya terdapat peningkatan yang signifikan hasil belajar kognitif siswa pada kedua kelas sebelum pembelajaran (pretest) dan sesudah pembelajaran (posttest).

Berdasarkan hasil analisis deskriptif dan inferensial diketahui bahwa terdapat peningkatan hasil belajar dan perbedaan daya serap yang signifikan antara kelas kontrol dan kelas eksperimen. Hal ini di dukung oleh penelitian Lusi Rahmawati (2015) dan Williyatimas (2005), yang membuktikan bahwa terdapat perbedaan signifikan terhadap hasil belajar siswa yang memperoleh pembelajaran treffinger dengan hasil belajar siswa yang memperoleh pembelajaran biasa.

Penelitian ini juga menunjukkan bahwa siswa dengan taraf sekolah menengah mengalami peningkatan yang signifikan dalam hal kemampuan memecahkan masalah secara kritis, setelah diberikan perlakuan dengan menerapkan model pembelajaran treffinger. Kelebihan dari penerapan model pembelajaran treffinger pada kelas eksperimen adalah siswa menjadi lebih aktif dan kreatif dalam proses pembelajaran.

Tabel 4. Hasil uji inferensial nilai kelas eksperimen dan kontrol

\begin{tabular}{|c|c|c|c|c|c|c|}
\hline & \multicolumn{2}{|c|}{ Pretest } & \multirow{2}{*}{ Ho } & \multicolumn{2}{|c|}{ Postest } & \multirow{2}{*}{ Ho } \\
\hline & Eksperimen & Kontrol & & Eksperimen & Kontrol & \\
\hline Normalitas & $p=0,200$ & $p=0,085$ & & $p=0,108$ & $p=0,086$ & \\
\hline Homogenitas & \multicolumn{2}{|c|}{$p=0,196$} & & \multicolumn{2}{|c|}{$p=0,482$} & \\
\hline $\begin{array}{l}\text { Independent } \\
\text { Sample T Test }\end{array}$ & \multicolumn{2}{|c|}{$p=0,602$} & diterima & \multicolumn{2}{|c|}{$p=0,003$} & ditolak \\
\hline
\end{tabular}


Model pembelajaran treffinger memberikan keluasan terhadap siswa dalam menemukan konsep serta memberikan kebebasan siswa dalam menemukan gagasan untuk menyelesaikan persoalan. Hal ini sangat berbeda dengan model pembelajaran konvesional. Akan tetapi model pembelajaran treffinger juga terdapat kelemahan selama proses pembelajaran, yaitu waktu yang dibutuhkan dengan model treffinger, lebih lama dibandingkan dengan pembelajaran konvesional, sehingga perlu pengendalian waktu yang lebih baik. Hal ini juga dinyatakan dalam penelitian (Fatimah, 2015) bahwa pada materi tertentu penggunaan model treffinger menyita waktu lebih lama.

\section{Kesimpulan dan Saran}

Berdasarkan penelitian yang telah dilaksanakan di SMA Negeri 9 Pekanbaru, maka dapat disimpulkan secara analisis deskriptif terdapat perbedaan daya serap ratarata siswa antara kelas eksperimen dengan kelas kontrol. Tingkat daya serap siswa kelas eksperimen yang menerapkan model treffinger berada pada kategori yang lebih tinggi. Selain itu, terdapat perbedaan tingkat efektivitas pembelajaran antara kelas kontrol dan kelas eksperimen. Tingkat efektivitas pembelajaran pada kelas eksperimen berada pada kategori yang lebih efektif dibandingkan dengan kelas kontrol yang cukup efektif. Secara inferensial terdapat perbedaan yang signifikan antara hasil belajar kognitif siswa pada kelas yang menggunakan model treffinger dibandingkan kelas konvensional di SMA Negeri 9 Pekanbaru. Oleh karena itu, penerapan model pembelajaran treffinger efektif dalam meningkatkan hasil belajar siswa kelas XI SMA Negeri 9 Pekanbaru pada materi optik.

Model pembelajaran treffinger dapat diterapkan dengan mengoptimalkan peran siswa dalam membentuk kreativitas. Model ini dapat digunakan sebagai salah satu alternatif dalam pembelajaran fisika yang inovatif. Selain itu, model pembelajaran ini, dapat diterapkan ini pada materi yang berbeda dan bidang ilmu yang berbeda dengan memperhatikan kesesuaian model, guna meningkatkan mutu pendidikan dimasa yang akan datang.

\section{Daftar Pustaka}

Andriyani Anik. (2015). Peningkatan kreativitas belajar matematika melalui penerapan metode team quiz pada peserta didik kelas V di SD Negeri 01 Gedong Kabupaten Karang Anyar tahun pelajaran 2014/2015. Thesis, UMR Surakarta.

Depdiknas. (2007). Petunjuk pelaksanaan proses belajar mengajar. Jakarta: Depdiknas.

Fatimah. (2015). Penggunaan model pembelajaran treffinger untuk meningkatkan hasil belajar kognitif peserta didik pada materi optika geometris kelas $\mathrm{X}$ Man Blora tahun pelajaran 2014/2015. Skripsi Pendidikan Fisika Fakultas Ilmu Tarbiyah dan Keguruan Universitas Islam Negeri Walisongo.Semarang.

Lusi Rahmawati. (2015). Pengaruh model pembelajaran treffinger terhadap kreativitas dan hasil belajar suhu dan kalor peserta didik.

Muhammad Noer. (2014). Peningkatan hasil belajar keterampilan psikomotor fisika melalui penerapan pembelajaran kreatif model treffinger pada peserta didik kelas X.A2 MA Darel Hikmah Pekanbaru. Skripsi. Pekanbaru: Fakultas Ilmu Pendidikan Universitas Riau. Diakses 4 Januari 2019.

Nurpatmawati, H., Islami, N., \& Fakhruddin. (2017). Analisis perubahan tingkat konsepsi sains fisika siswa menggunakan model pembelajaran Poe (predict-observe-explain) pada materi momentum dan impuls kelas X MAN 1 Pekanbaru. Jurnal Online Mahasiswa (JOM) Bidang Keguruan dan Ilmu Pendidikan, 4(2), 1-9.

Rizki Amalia. (2012). Analisis tingkat pemahaman konsep fisika dan kemampuan berfikir kritis peserta didik pada pembelajaran dengan model creative problem solving (CPS). Tesis, Medan: Program Pascasarjana Universitas Negeri Medan, http://digilib.unimed.ac.id/258878106176019.html.

Sari, Y. I., \& Putra, D. F. (2015). Pengaruh model pembelajaran treffinger terhadap kemampuan berpikir kritis dan kreatif maha peserta didik Universitas Kanjuruhan Malang. Jurnal Pendidikan 
Geografi, 20(2). Universitas Kanjuruhan Malang.

Sugiyono. (2017). Metode penelitian kuantitatif, kualitatif, dan $R \& D$. Bandung: Alfabeta.

Suharsimi Arikunto. (2016). Penelitian tindakan kelas. Jakarta: Bumi Aksara.
Williyatimas. (2005). Penerapan model treffinger dalam pembelajaran matematika untuk meningkatkan kemampuan pemecahan masalah peserta didik kelas II SMP ditinjau dari peringkat sekolah. Disertasi Pascasarjana UPI. Bandung. 